Original Article

\title{
Trophic ecology of Acestrorhynchus falcirostris Cuvier, 1819 in island lakes on the lower stretch of the Solimões River, Amazon Basin
}

\author{
Ecologia trófica de Acestrorhynchus falcirostris Cuvier, 1819 em lagos de ilha no trecho \\ inferior do Rio Solimões, Bacia Amazônica
}

\author{
C. Lubicha* (D), J. Aguiar-Santos $^{\text {b }}$ (D), F. Corrêac (D, C. E. C. Freitas ${ }^{\mathrm{d}}$ (1) and F. K. Siqueira-Souzad (D) \\ anniversidade Federal do Amazonas - UFAM, Programa de Pós-graduação em Ciência Animal e Recursos Pesqueiros, Manaus, AM, Brasil \\ 'Instituto Nacional de Pesquisas na Amazônia - INPA, Programa de Pós-graduação em Ecologia, Manaus, AM, Brasil \\ cUniversidade do Estado de Mato Grosso - UNEMAT, Programa de Pós-graduação em Ecologia e Conservação, Nova Xavantina, MT, Brasil \\ dUniversidade Federal do Amazonas - UFAM, Departamento de Ciências Pesqueiras, Manaus, AM, Brasil
}

\begin{abstract}
The aim objective of this study was to determine the trophic ecology of juvenile and adult Acestrorhynchus falcirostris during the rising and flood (high-water) period in six island lakes adjacent to the Solimões River. As such, we investigated: i) the trophic position, through the fractional trophic niche; ii) the niche breadth; iii) niche overlap and iv) the food strategy of the species. The specimens were collected during the years 2014 to 2017, using gillnets with mesh sizes ranging from 30 to $120 \mathrm{~mm}$ between opposite knots. Through the analysis of stomach contents, the preference in the consumption of items of animal origin was observed. Juveniles consumed insects in greater proportions (IAi\% = 50\%), while adults consumed fish (IAi\%=99,98\%). Despite the large supply of food items available in the high-water period, juveniles were the only ones to consume items of allochthonous origin, such as insects. Juveniles presented a different dietary strategy and dietary composition to adults. Juveniles were omnivores with a generalist strategy, while adults were piscivores with a specialist strategy. Thus, the food composition, niche breadth, trophic position and feeding strategy of Acestrorhynchus falcirostris change due to the stage of development.

Keywords: feeding selectivity, feeding strategy, niche breadth, predator, trophic level.

Resumo

O objetivo deste estudo foi determinar a ecologia trófica de juvenis e adultos de Acestrorhynchus falcirostris durante o período de enchente e cheia em seis lagos de ilha adjacentes ao rio Solimões. Assim, investigamos: i) a posição trófica, através do nicho trófico fracional; ii) a largura de nicho; iii) sobreposição de nicho; iv) a estratégia alimentar. Os espécimes foram coletados durante os anos de 2014 a 2017, utilizando redes de emalhar com malha variando de 30 a 120mm entre nós opostos. Por meio da análise do conteúdo estomacal, observamos a preferência no consumo de itens de origem animal. Os juvenis consumiram insetos em maiores proporções (IAi\% $=50 \%$ ), enquanto os adultos consumiram preferencialmente peixes ( $\mathrm{IAi} \%=99,98 \%$ ). Apesar da grande oferta de alimentos disponíveis no período da cheia, os juvenis eram os únicos a consumir itens de origem alóctone, como por exemplo, os insetos. Os juvenis apresentaram uma estratégia alimentar e composição alimentar diferente para os adultos. Os juvenis foram considerados onívoros com uma estratégia generalista, enquanto os adultos foram considerados piscívoros com uma estratégia alimentar mais especialista. Assim, a composição alimentar, amplitude do nicho, posição trófica e a estratégia alimentar de Acestrorhynchus falcirostris muda em função do estágio de desenvolvimento.
\end{abstract}

Palavras-chave: seletividade alimentar, estratégia alimentar, amplitude de nicho, predador, nível trófico.

\section{Introduction}

In lakes of the Amazon floodplain, food items and habitat availability are directly and indirectly influenced by the flood pulse (Junk et al., 1989). During the flood period, fish species are favored by the expansion and lateral connection of flooded forest areas, which for fish allows for the greater consumption, for example, of fruits and seeds, terrestrial and aquatic invertebrates, as well as plant material and debris/sediment (Lourenço et al., 2012; Zuanon and Ferreira, 2008). In fact, the high-water period provides an increase in the diversity of food items, in which fish species, including those of predatory fish, benefit from the quantity and quality of available items. This creates

*e-mail: lubichchiara@gmail.com

Received: July 2, 2021 - Accepted: November 18, 2021

This is an Open Access article distributed under the terms of the Creative Commons Attribution License, which permits unrestricted use, distribution, and reproduction in any medium, provided the original work is properly cited. 
an opportunity for the accumulation of energy reserves for survival during the low water period when there is a reduction in the supply of food items (Claro-Jr et al., 2004; Goulding, 1980; Zuanon and Ferreira, 2008).

Because of the alterations in the supply of food items caused by the predictable fluvial dynamics, some species present high food plasticity and exploit a wide variety of prey, while others tend to be more specialist and consume only one or a few types of prey. These different eating patterns are can occur at the inter-and intra-specific level, in this last relationship, for example, influenced by the stage of development of individuals of the same species (Ward et al., 2006). According to Ward et al. (2006) the density of adult individuals in a certain area decreases the feeding rates of juveniles. Thus, due to competition for food, the degree of dietary variation is influenced (Araújo et al., 2011; Svanbäck et al., 2011), and consequently influencing dietary composition, and other trophic aspects, which can be verified by the niche breadth (Krebs, 1998), trophic level (Amezcua et al., 2011), niche overlap (Pianka, 1973) and feeding strategy (Gerking, 1994; Wootton, 1990. These changes occur to optimize foraging efficiency and increase individual performances (Bolnick et al., 2003; Svanbäck and Bolnick, 2008).

In the lakes of the floodplains of the Amazon, nearly half of the fish species are piscivorous (Freitas et al., 2010; Macedo et al., 2015; Mérona and Rankin-de-Mérona, 2004), and among these piscivorous species that live in these environments is Acestrorhynchus falcirostris (Cuvier, 1819), which is one of the most abundant and widely distributed species along the floodplains of the major tropical rivers (Farias et al., 2017; Hawlitschek et al., 2013). Studies regarding the diet of $A$. falcirostris have already been performed by evaluating, for example, the composition of the diet (Hawlitschek et al., 2013; Mérona and Rankin-de-Mérona, 2004), effects of seasonality on energy acquisition (Neves dos Santos et al., 2008), energy allocation for reproduction (Neve dos Santos et al., 2010), the relationship between their feeding strategy and hydrology (Röpke et al., 2019) and diet and morphological relationships (Cardoso et al., 2019). However, studies on the niche breadth, fractional trophic position and feeding strategy for A. falcirostris have not yet been performed. Thus, knowledge about the trophic ecology of predatory fish, as A. falcirostris, is necessary, as they are considered biological regulators and feed on some prey species that have economic and social importance.

Therefore, knowing that trophic plasticity may be associated with stage of development, the questions that motivated this study was "in the Amazonian floodplain lakes, are there changes in the trophic ecology of Acestrorhynchus falcirostris related to the stage of development (juveniles and adult) in the rising and/or the flood pulse? Considering the following important ecological issues: i) the trophic position that juveniles and adults of the species occupy, through the fractional trophic niche; ii) the niche breadth and iii) niche overlap of juveniles and adults; and iv) the feeding strategy of juveniles and adults of the species.

\section{Material and Methods}

\subsection{Study area}

The study was conducted in six lakes located on a fluvial island in the Solimões River. Paciência Island is a fluvial island situated on the main channel of the lower stretch of the Solimões River (Figure 1). The Solimões headwaters are located in the Andes (Franzinelli, 2011), their waters are

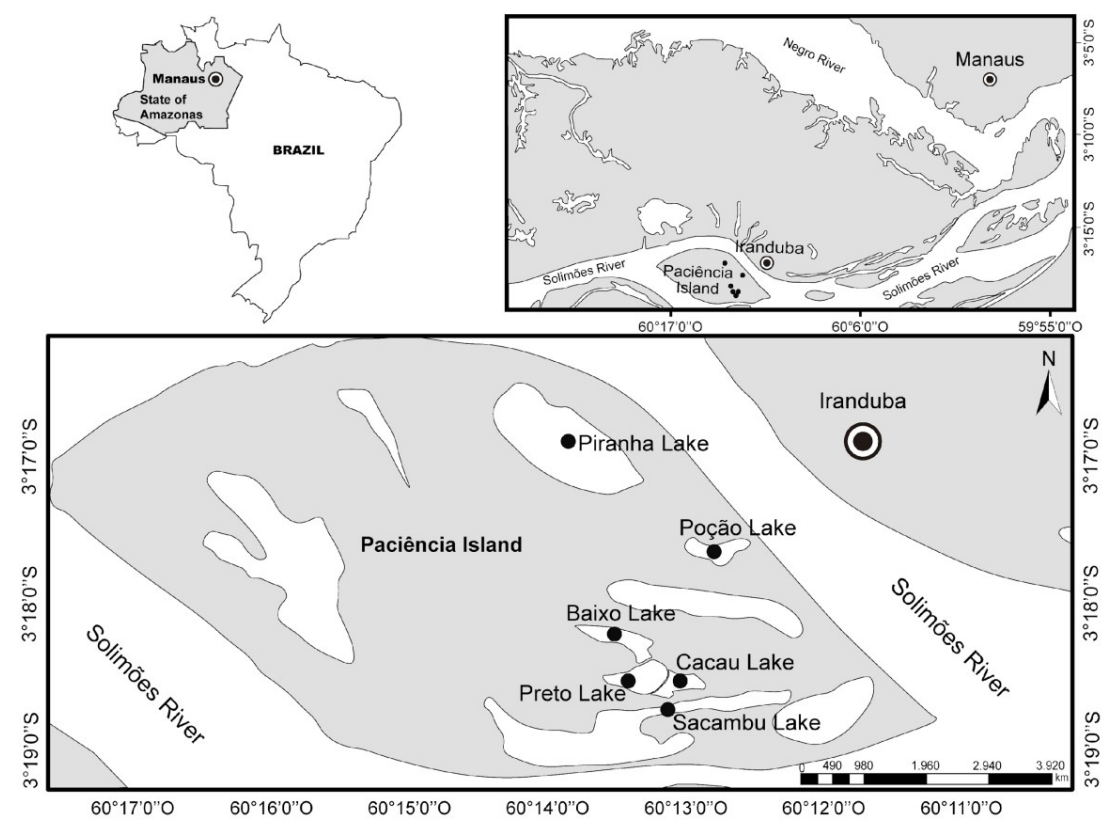

Figure 1. Image of the study area referring to the location of the floodplain lakes. 
classified as white, are weakly acidic to neutral (6.5 - 7.0) (Sioli 1984; Queiroz et al., 2009; Villamizar et al., 2020). According to Sioli (1984), the water temperature remains at $29 \pm 1^{\circ} \mathrm{C}$ during the year. Solimões River is composed up of a complex system of environments, as river channels, lakes, islands and levees, which give rise to a diversity of habitats that are fundamental for the various uses of water resources, whether by riverside dwellers or by fauna and flora, due to high fish productivity and soil fertility (Sioli 1951; Moreira 1977).

The lakes were formed behind scroll bars that were created by the overbank deposition of fine material (Mertes et al., 1996). The island lakes are strongly influenced by the annual hydrological cycle and vary between complete connectivity among lakes and the main channel of the river during high water period, and loss of connectivity among lakes and the river when the waters recede during the low water period (Junk et al., 1989). The temperature of the island lakes varies between $31.3-32.7^{\circ} \mathrm{C}\left(31.1 \pm 0.490{ }^{\circ} \mathrm{C}\right)$ and the depth between 1.8 - $4.3 \mathrm{~m}(2.52 \pm 0.902 \mathrm{~m})$ (Freitas et al., 2014).

In the high-water period, due to the expansion of the flooded areas that cause the dispersion of organisms toward the flooded forest and the aquatic herbaceous plants, greater access is provided to allochthonous items, and many species take advantage of the situation in order to gain a fat reserve when the supply of food is at its greatest (Goulding, 1990). These lakes have a high diversity of fish species, due to greater connectivity with the main river, during the high-water period (Freitas et al., 2014).

\subsection{Sampling}

Four sampling events took place during the rising and flood period over three years (2014 to 2017) (see Table 1). To determine the season of the hydrological cycle, the river level for the date of collection, which is measured in the harbor in Manaus (Porto de Manaus, 2021) and criteria adopted by Bittencourt and Amadio (2007) were used.

\subsection{Methods}

Fish captures were performed under authorization of SisBio (Number: 50662-1) and licensed by the Ethics Committee for Animal Use at the Federal University of Amazonas, under authorization number 056/2017 (CEUA - UFAM). The fish samplings were made using gill nets with standardized dimensions of $15 \mathrm{~m}$ in length by $2 \mathrm{~m}$ in height and mesh sizes of $30,40,50,60,70,80,90,100$, 110 and $120 \mathrm{~mm}$ between opposite knots. The sampling

Table 1. Average river level values obtained for the date of collections performed in the floodplain lakes of the Solimões River, Amazon basin.

\begin{tabular}{cccc}
\hline Year & Month & River level average $(\mathbf{m})$ & Season \\
\hline 2014 & May & 28.71 & Flood \\
& November & 20.22 & Rising \\
2016 & March & 23.10 & Rising \\
2017 & April & 27.93 & Flood \\
\hline
\end{tabular}

time also was standardized in 12 hours with fish collection occurring every six hours. The individuals were identified with the aid of ichthyological keys (Santos et al., 2009; Soares et al., 2007) and the help of specialists. After identification, all captured individuals were measured for standard length $(\mathrm{cm})$ and weighed as total weight $(\mathrm{g})$. After that, the stomachs of $A$. falcirostris were removed by a ventral incision, labeled and stored in a freezer $\left(-20^{\circ} \mathrm{C}\right)$.

\subsection{Stomach content analysis}

The analysis of stomach contents was performed at the Fisheries Ecology Laboratory (LABEP) at the Federal University of Amazonas. Food items were analyzed with the aid of an optical microscope and magnifying glass, and identified to the lowest possible taxonomic level using identification keys (Hamada and Ferreira-Keppler, 2012; Santos et al., 2009; Soares et al., 2007) and consultation with specialists.

In order to identify ontogenetic variations in the diet of the species, the A. falcirostris samples were divided into two size classes according to the length at first sexual maturation: $<15 \mathrm{~cm}$ (juveniles) and $\geq 15 \mathrm{~cm}$ (adults) (Dieb-Magalhães et al., 2015). Food analysis was performed according to the items consumed by each size class.

\subsection{Data analyses}

Only fish with stomachs showing more than $25 \%$ of filling were included in the analysis, due to the amount of food item found in the stomach, $25 \%$ being the lowest degree of fullness used in the analysis. Diet composition was analyzed using the volumetric method (V\%) and frequency of occurrence (FO\%) (Hynes, 1950; Hyslop, 1980). These two parameters were combined to estimate the alimentary index (IAi\%) (Kawakami and Vazzoler, 1980) through the formula: $\mathrm{IAi}=\mathrm{Fi} * \mathrm{Vi} / \Sigma(\mathrm{Fi} * \mathrm{Vi})$; where $\mathrm{IAi}=$ Alimentary Index, $\mathrm{i}=$ food item, $\mathrm{Fi}$ = frequency of occurrence $(\%)$ of $\mathrm{i}$ food item, and $\mathrm{Vi}=$ volume relative $(\%)$ of $\mathrm{i}$ food item.

From the values obtained for the IAi\% according to the food categories, the fractional trophic level of the species was calculated using the TrophLab program (Pauly et al., 2000). The calculation expresses the position of the species studied in the food chain (Amezcua et al., 2011). The fractional trophic levels present values may range from 1.0 to 5.0, with the interval from 1.0 to 1.9 identifying primary producers and feeders on debris/sediment, 2.0 to 2.9 identifies herbivores, 3.0 to 3.9 identifies omnivores, and 4.0 to 5.0 identifies carnivores and piscivores (Pauly and Palomares, 2000).

The trophic niche breadth of the species, calculated for juveniles and adults according to the Levin's Index $\left(\mathrm{B}_{\mathrm{A}}\right)$ (Krebs, 1998) through the formula: $B A=(B-1) /(n-1)$, where BA is the Levin's Standard is ed Index by the number items (n) and $B=1 / \sum_{i=1}^{n} p i^{2}$, where $\mathrm{B}=$ trophic niche breadth, $\mathrm{p}_{\mathrm{i}}$ is the proportion of the item $\mathrm{i}$ in the diet, and $\mathrm{n}$ is the number of food items. Trophic niche data were standardized to express niche breadth on a scale from 0 to 1 , as suggested by Hurlbert apud Krebs (1998). The value is closer to 0 when most of the prey items belong to the same species 
(specialised diet), and closer to 1 when the predator does not discriminate among resources (generalist).

Feeding overlap was measured for juvenile and adult using the Pianka Index (Pianka, 1973), according to the formula: $O_{i j}=\sum_{i}^{n} p_{i j} p_{i k} / \sqrt{\sum_{i}^{n} p_{i j}{ }^{2}} \sum_{i}^{n} p_{i k}{ }^{2}$, where $\mathrm{O}_{\mathrm{ij}}$ is the Pianka's measure of niche overlap index between $j$ (juvenile) and $k$ (adult) individuals, $\mathrm{p}_{\mathrm{ij}}$ is proportion resource $I$ of the total resources used by $j, \mathrm{p}_{i k}$ is proportion resource $I$ of the total resources used by $k$, and $n=$ total number of resource states.

The Pianka overlap index ranges from 0 (no overlap) to 1 (complete overlap), and might be indicative of competition or partition resources. An arbitrary scale was defined to explain the values obtained from niche overlap. Defined at the following levels according to Grossman (1986) and Novakowski et al. (2008): high (>0.6), intermediate $(0.4-0.6)$ or low $(<0.4)$.

To evaluate the feeding strategy, we produced the graph proposed initially by Costello (1990) and later modified by Amundsen et al. (1996) through the formula: $\% \mathrm{~F}_{\mathrm{i}}=\left(\mathrm{N}_{\mathrm{i}} / \mathrm{N}\right)^{*} 100$, where: \%F is percent occurrence of prey type $i, \mathrm{~N}_{\mathrm{i}}=$ number of predators, with prey $\mathrm{i}$ in your stomach, $\mathrm{N}=$ total number of predators with stomach contents, and $\mathrm{P}_{\mathrm{i}}=\left(\sum \mathrm{S}_{\mathrm{i}} / \sum \mathrm{S}_{\mathrm{t}}\right)^{*} 100$, where: $\mathrm{P}_{\mathrm{i}}$ is the specific abundance of prey $i, \mathrm{~S}_{\mathrm{i}}=$ volume of stomach contents composed of prey $i$ and total volume of the stomachs of predators that consumed only the prey $i$.

Finally, a simulation was performed with the food strategy model proposed initially by Costello (1990). Thus, the entry indices into the model (percentage occurrence and percentage abundance of prey type) were carried out by removing the most abundant species in the diet of juveniles and adults, therefore, the indices were performed for the other food items. This simulation was carried out to show how the absence of the preferred prey species can modify the food strategy of a predatory fish species.

Explanation of the model result initially proposed by Costello (1990) and later modified by Amundsen et al. (1996) - Prey specific abundance is represented as a function of the frequency of occurrence in a two-dimensional graph. The importance of prey and predator feeding strategy can be interpreted by visualizing point distributions along the diagonals and axes of the diagram. Abundance percentage increasing along the diagonal, from the lower left corner to the upper right corner, shows the importance of prey in feeding the species. The vertical axis represents the predator's feeding strategy in terms of specialization or generalization.

\section{Results}

A total of 145 adults and 11 juvenile $A$. falcirostris were collected and used in the analysis. Weights and lengths ranged from $31-466$ grams $(129.87 \mathrm{~g} \pm 67.38)$ and $13-33 \mathrm{~cm}$ $(22.44 \mathrm{~cm} \pm 3.92)$, respectively.

Six types of prey were identified in the diet of juvenile fish and 16 types in the diet of adults. The insect item $(\mathrm{IAi}=50.0 \%)$, followed by fish item $(\mathrm{IAi}=40.9 \%)$ were the most important in the diet of the juveniles, while the fish item was predominant important in the adult diet $(\mathrm{IAi}=$ $99.98 \%$ ) (Table 2 ).

Plant material was found predominantly in the stomach contents of the juveniles, but also accidentally in the stomach of adults. Insects, Odonata ( $\mathrm{IAi}=36.36 \%)$ and fishes, Triportheus spp. $(\mathrm{IAi}=22.73 \%)$ were the most important food items for juvenile A. Falcirostris. Triportheus spp. presented an IAi equal to $91.69 \%$ in the diet of adult individuals, was thus the most important prey of their diet. A. falcirostris presented cannibalism, ingesting individuals of the same genus, but with low participation. (Table 2 ).

The trophic levels for juvenile and adult A. falcirostris, estimated according to the TrophLab, were 3.27 (standard error $=0.62$ ) and 4.43 (standard error $=0.79$ ), respectively. The value for juveniles was influenced by the consumption of insects ( $\mathrm{IAi}=50 \%$, while in adults the high consumption of fish causes a high value ( $\mathrm{IAi}=99.98 \%)$.

The trophic niche breadth calculated by the Levin's Index showed differences between juvenile and adult fish. Juvenile $A$. falcirostris showed a smaller niche breadth $\left(B_{A}=0.04\right)$, indicating the consumption of fewer items in larger proportions (e.g., Odonata, $\mathrm{FO} \%=33 \%$ and Triportheus spp., FO $=20 \%$ ), while adults had a higher niche breadth $\left(B_{A}=0.81\right)$, since they consumed a greater variety of items in equivalent proportions (Table 2). Pianka's index of niche overlap showed an intermediate value between juvenile and adult fish (0.485), which can be explained by the partition of only three food items, Triportheus spp., Hemiodus unimaculatus and plant material (Table 2).

According to the feeding strategy graph, it can be noted that, for juveniles and adults, almost all prey consumed are at the bottom of the graph, showing a generalist strategy, that is, they consume these items occasionally (Figure 2A). However, the prey positioned in the upper left part of the diagram, such as Triportheus spp. for adults, reflects a specialization, for only some individuals of $A$. falcirostris (Figure 2B). If carefully observed, it is possible to notice that the prey is distributed along and below the diagonal, suggesting that the population has a wide niche breadth (Figures 2A and 2B).

According to the simulation performed there were no changes for the juvenile A. falcirostris, however for adults the removal of the species can increase the proportion that other fish species, such as $H$. unimaculatus are ingested. However, there was no indication of a specialization behavior, since all items are in the rare prey quadrant (Figures $3 \mathrm{~A}$ and $3 \mathrm{~B}$ ). Thus, the generalist or opportunistic feeding strategy of $A$. falcirostris becomes evident, regardless of the stage of development.

\section{Discussion}

The analysis of the stomach contents of A. falcirostris showed carnivory as a feeding habit for both juvenile individuals and adults, but with changes in composition throughout ontogenetic development, in which juveniles of $A$. falcirostris showed the consumption of insects in a greater proportion, while adults ate fish almost exclusively. 
Table 2. Frequency of occurrence (FO\%) and alimentary index (IAi\%) values for juvenile and adult $A$. falcirostris collected during the years 2014 to 2017, using gillnets with mesh size ranging from 30 to $120 \mathrm{~mm}$ between opposite knots in the floodplain lakes of the Solimões River, Amazon basin.

\begin{tabular}{|c|c|c|c|c|c|}
\hline \multicolumn{2}{|r|}{ PREY FISH } & \multicolumn{2}{|c|}{$\begin{array}{c}\text { JUVENILES } \\
(\mathrm{N}=11)\end{array}$} & \multicolumn{2}{|c|}{$\begin{array}{l}\text { ADULTS } \\
(\mathrm{N}=145)\end{array}$} \\
\hline Family & Species & FO (\%) & IAi (\%) & FO (\%) & IAi (\%) \\
\hline Pristigasteridae & Pellona spp. & & & 0.02 & 0.05 \\
\hline \multirow[t]{3}{*}{ Serrasalmidae } & Mylossoma spp. & & & 0.01 & 0.01 \\
\hline & Pygocentrus nattereri Kner, 1858 & & & 0.02 & 0.05 \\
\hline & Serrasalmus spp. & & & 0.05 & 0.28 \\
\hline \multirow[t]{2}{*}{ Hemiodontidae } & Hemiodus unimaculatus (Bloch, 1794) & 0.13 & 18.18 & 0.13 & 2.30 \\
\hline & Anodus spp. & & & 0.06 & 0.44 \\
\hline Anostomidae & Rhytiodus microlepis Kner, 1858 & & & 0.05 & 0.37 \\
\hline \multirow[t]{2}{*}{ Curimatidae } & Potamorhina spp. & & & 0.13 & 2.23 \\
\hline & Psectrogaster spp. & & & 0.13 & 2.27 \\
\hline Prochilodontidae & Semprochilodus spp. & & & 0.04 & 0.21 \\
\hline Triportheidae & Triportheus spp. & 0.20 & 22.73 & 0.27 & 91.69 \\
\hline Acestrorhynchidae & Acestrorhynchus spp. & & & 0.01 & 0.02 \\
\hline Pimelodidae & Hypophthalmus spp. & & & 0.01 & 0.02 \\
\hline Loricariidae & Hypoptopoma spp. & & & 0.01 & 0.02 \\
\hline Cichlidae & Heros severus Heckel, 1840 & & & 0.01 & 0.02 \\
\hline \multicolumn{6}{|l|}{ OTHER PREY } \\
\hline \multirow[t]{3}{*}{ Insects } & Coleoptera & 0.13 & 9.09 & & \\
\hline & Odonata & 0.33 & 36.36 & & \\
\hline & Orthoptera & 0.07 & 4.55 & & \\
\hline Plant Material & Plant Material & 0.13 & 9.09 & 0.03 & 0.02 \\
\hline
\end{tabular}

$\mathrm{N}=$ sample size.
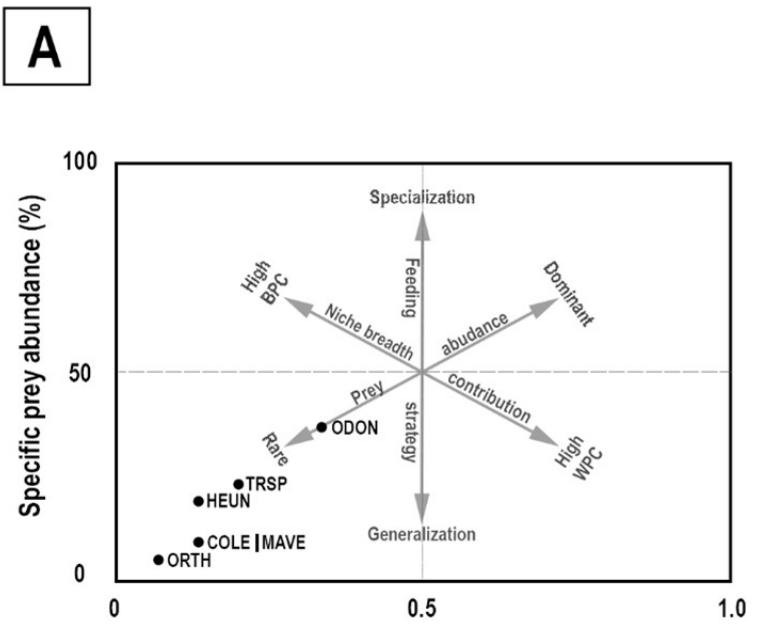

\section{Frequency Occurrence}

Figure 2. Graphical representation of the feeding strategy of (A) juvenile and (B) adult A. falcirostris. High BPC= High between-phenotype component to niche width; High WPC= high within-phenotype component; COLE = Coleoptera; HEUN = Hemiodus unimaculatus; MAVE = Plant material; ODON = Odonata; ORTH = Orthoptera; POSP = Potamorhina spp.; PSSP = Psectrogaster spp.; TRSP = Triportheus spp. 


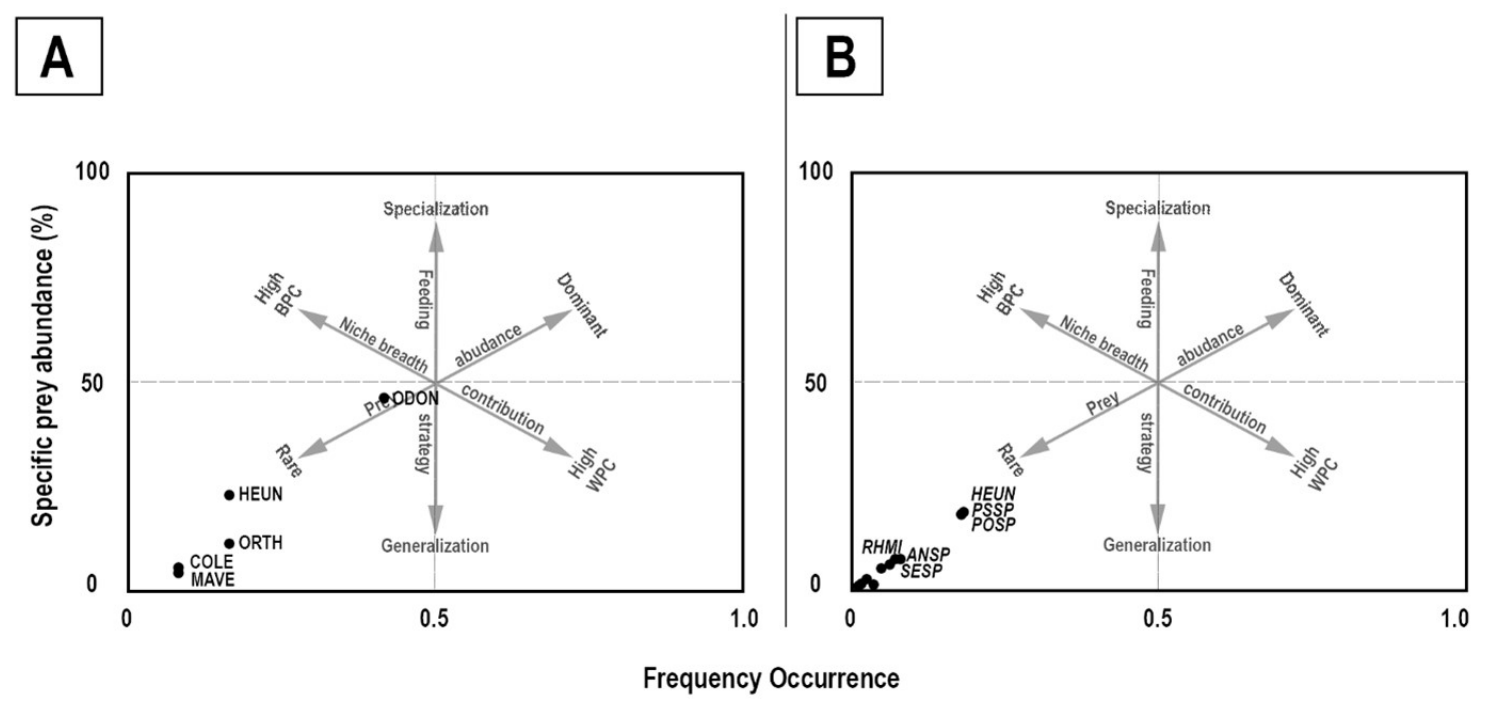

Figure 3. Graphic representation of the feeding strategy of (A) juvenile and (B) adult A. falcirostris, with the removal of Triportheus spp. from the diet. High $\mathrm{BPC}=$ High between-phenotype component to niche width; High WPC= high within-phenotype component; MAVE = Plant material; ODON = Odonata; ORTH = Orthoptera; $\mathrm{COLE}=$ Coleoptera; RHMI= Rhytiodus microlepis; ANSP= Anodus spp.; SESP= Serrasalmus spp.; HEUN= Hemiodus unimaculatus; PSSP= Psectrogaster spp.; POSP= Potamorhina spp.

However, in the graphic representation as per Amundsen et al. (1996), it was evident that juveniles and adults consumed mostly occasional items (generalization), although some adult individuals presented individual specializations, such as in the consumption of Triporteus spp. Considering that within a population there are individuals that have more developed physical characteristics than others (example: vision, speed and adapted hunting tactics), species of abundant and low-occurrence prey, that is, prey that does not occur throughout the year, but when they do occur, it is in great quantity, will be consumed by more specialized individuals, while prey with low abundance and high occurrence, that is, prey species found throughout the year, but in small numbers, will occasionally be consumed by more generalist individuals of the population (Amundsen et al., 1996). These differences are highly related to the phenotypic component among and within the contributions to niche breadth (Amundsen et al., 1996).

The generalist strategy found in the study corroborates with the reported in the literature for predatory fish (Cardoso et al., 2019; Jacobi et al., 2020; Mérona and Rankin-de-Mérona, 2004), since, in this seasonal phase, there is a greater supply of allochthonous items of animal and vegetable origin, such as winged insects, fruits and seeds that fall from the trees (Claro-Jr et al., 2004; Goulding, 1990) and serve as food for fish. This phase also aids the fish by allowing them to store fat until the low water period, when food becomes scarce. This strategy may be more important for juvenile individuals who have limitations in regard to capturing larger prey, but it can also be associated with metabolic demand and avoidance of competition for food with larger individuals (Ward et al., 2006).

Thus, A. falcirostris can alternate between generalist and specialist strategies, depending on its stage of development. As such, the variation of river water levels in lowland environments tends to alter the availability of food items for the fish (Mérona and Rankin-de-Mérona, 2004), and affects the trophic patterns of most species that inhabit these dynamic environments, especially in regards to the supply of prey for predatory fish (Correa and Winemiller, 2014; Wootton, 1990).

Studies on the diet of species of the genus Acestrorhynchus have revealed the piscivorous feeding habits of juvenile and adult individuals in other hydrological periods and in other water basins (Bozza and Hahn, 2010; Dourado et al., 2015; Krinski, 2010; Meurer and Zaniboni-Filho, 2012; Rocha et al., 2011; Silva and Goitein, 2009), with the majority of the prey belonging to the Characiformes order.

As observed in this study, the occurrence of ingestion of its congeners has already been reported as an indication of cannibalism (Dourado et al., 2015; Krinski, 2010; Rocha et al., 2011), the same pattern of cannibalism was found by Gomiero et al. (2010) for another predatory fish species, Cichla kelberi, introduced in an artificial lake in southeastern Brazil. In the Pantanal of Mato Grosso, Brazil, Lipparelli (1999) demonstrated that, during the rainy season, there is an increase in the turbidity of the water, causing a decrease in visibility by the predator and the capture of individuals of the same species may occur. The same may have occurred in the present study, since the Amazonian floodplain lakes have little visibility due to the large amount of dissolved material suspended in the water (Latrubesse, 2012).

The terminal mouth shape, large mandibular opening and huge canine teeth also help in capturing prey, as well as the gills rakers that are smaller and more spaced apart to trap food inside the oral cavity (Rotta, 2003; Ramírez et al., 2015; Cardoso et al., 2019). Another factor that facilitates the type of intake is the bag shape (or pisciform) of the stomach of A. falcirostris, with elastic musculature to accommodate the whole prey in the celomatic cavity (Rotta, 2003), since 
most of the fish consumed by A. falcirostris are of fusiform shapes, such as Triportheus spp., which aids the entire prey intake when compared to rhomboid-shaped fish. Therefore, the most consumed prey has a direct association with the morphology of the predator, availability of prey (Correa and Winemiller, 2014). However, aspects such as population density of prey (Neves dos Santos et al., 2008) and nutritional requirement of the predator (Rotta, 2003; Brandão-Gonçalves and Sebastien, 2013), can also justify the preferential ingestion of some prey.

Juveniles and adults presented different fractional trophic niches, as well as differences in niche breadth. According to the classification of Pauly and Palomares (2000), the estimated value found for fractional trophic niche for juvenile specimens included them as omnivores (ranging from 3 to 3.9), while adults were classified as carnivores/piscivores (ranging from 4 to 5 ). Wootton (1990) and Villares Junior and Goitein (2016) suggests that juveniles are selective because their intake is limited by the mouthpiece opening and locomotor capacity. However, as individuals from $A$. falcirostris grow, they become able to consume larger prey, which explains the difference observed in the trophic niche amplitude analysis (Houde, 1997). The consumption of larger prey according to the size of the predator has already been reported for other species of Acestrorhynchus, such as A. pantaneiro (Krinski, 2010) and A. lacustris (Bozza and Hahn, 2010; Hahn et al., 2000), indicating that diversity increases with predator size.

Among the species consumed, Triportheus spp. was the only prey shared by juveniles and adults, which shows it to be an important food item. The high consumption of this food item may reflect the high abundance of prey in the environment, since they are shoal-forming species, which can be found in abundance during the high-water period (Ponte et al., 2016; Santos et al., 2009). As well as this high abundance, it can also be associated with reproductive tactics and food availability, which together can play a fundamental role in the high population growth of the species.

Thus, our data suggest that juvenile $A$. falcirostris are omnivores, while adults are specialist piscivores. In synthesis, we propose that the feeding strategy adopted by this species may change depending on its stage of development. The information presented here contributes to the expansion of knowledge on the diet of A. falcirostris, and understand which species their diet is based on, as predator species are considered biological regulators and some fish species are captured for consumption and sale purposes, as well as a subsidy to future studies on the trophic ecology of fish species from floodplain areas of the Amazon. However, additional studies should be conducted to investigate ontogenetic variations, as well as the influence of river level variation on trophic ecology.

\section{Acknowledgements}

We are indebted to the Universidade Federal do Amazonas, Fundacão de Amparo à Pesquisa do Estado do Amazonas (FAPEAM; POSGRAD 2020/2021 - Resolution 006/2020), Coordenacão de Aperfeiçoamento de Pessoal de
Níıvel Superior - Brazil (CAPES) and to the "Seu Ivanildo" for assistance with collections.

\section{References}

AMEZCUA, F., PORTILLO, A. and AMEZCUA-LINARES, F., 2011. Feeding habits of the toothed flounder Cyclopsetta querna (Paralichthyidae) of the south-east Gulf of California. Journal of the Marine Biological Association of the United Kingdom, vol. 91, no. 6, pp. 1225-1230. http://dx.doi.org/10.1017/ S0025315410000603.

AMUNDSEN, P.A., GABLER, H.M. and STALDVIK, F.J., 1996. A new approach to graphical analysis of feeding strategy from stomach contents data-modification of the Costello (1990) method. Journal of Fish Biology, vol. 48, no. 4, pp. 607-614.

ARAÚJO, M.S., BOLNICK, D.I. and LAYMAN, C.A., 2011. The ecological causes of individual specialization. Ecology Letters, vol. 14, no. 9, pp. 948-958. http://dx.doi.org/10.1111/j.1461-0248.2011.01662.x. PMid:21790933.

BITTENCOURT, M.M. and AMADIO, S.A., 2007. Proposta para identificação rápida dos períodos hidrológicos em áreas de várzea do rio Solimões-Amazonas nas proximidades de Manaus. Acta Amazonica, vol. 37, no. 2, pp. 303-308. http:// dx.doi.org/10.1590/S0044-59672007000200019.

BOLNICK, D.I., SVANBÄCK, R., FORDYCE, J.A., YANG, L.H., DAVIS, J.M., HULSEY, C.D. and FORISTER, M.L., 2003. The ecology of individuals: incidence and implications of individual specialization. American Naturalist, vol. 161, no. 1, pp. 1-28. http://dx.doi.org/10.1086/343878. PMid:12650459.

BOZZA, A.N. and HAHN, N.S., 2010. Uso de recursos alimentares por peixes imaturos e adultos de espécies piscívoras em uma planície de inundação neotropical. Biota Neotropica, vol. 10, no. 3, pp. 217-226. http://dx.doi.org/10.1590/S1676-06032010000300025.

BRANDÃO-GONÇALVES, L. and SEBASTIEN, N.Y., 2013. Feeding activity and influence of intraspecific competition on zooplankton communities by jundiá (Rhamdia quelen Quoy and Gaimard, 1824) in laboratory. Brazilian Journal of Biology = Revista Brasileira de Biologia, vol. 73, no. 4, pp. 765-773. http://dx.doi. org/10.1590/S1519-69842013000400012. PMid:24789392.

CARDOSO, D.C., DEHART, P., FREITAS, C.E.C. and SIQUEIRA-SOUZA, F.K., 2019. Diet and ecomorphology of predator fish species of the Amazonian floodplain lakes. Biota Neotropica, vol. 19, no. 3, pp. e20180678. http://dx.doi.org/10.1590/1676-0611bn-2018-0678.

CLARO-JR, L., FERREIRA, E., ZUANON, J. and ARAUJO-LIMA, C., 2004. $O$ efeito da floresta alagada na alimentação de três espécies de peixes onívoros em lagos de várzea da Amazônia Central, Brasil. Acta Amazonica, vol. 34, no. 1, pp. 133-137. http://dx.doi. org/10.1590/S0044-59672004000100018.

CORREA, S.B. and WINEMILLER, K.O., 2014. Niche partitioning among frugivorous fishes in response to fluctuating resources in the Amazonian floodplain forest. Ecology, vol. 95, no. 1, pp. 210-224. http://dx.doi.org/10.1890/13-0393.1. PMid:24649660.

COSTELLO, M.J., 1990. Predator feeding strategy and prey importance: a new graphical analysis. Journal of Fish Biology, vol. 36, no. 2, pp. 261-263. http://dx.doi.org/10.1111/j.1095-8649.1990.tb05601.x.

DIEB-MAGALHÃES, L., FLORENTINO, A.C. and SOARES, M.G.M., 2015. Length-weight relationships and length at first maturity for nine fish species of floodplain lakes in Central Amazon (Amazon Basin, Brazil). Journal of Applied Ichthyology, vol. 31, no. 6, pp. 1182-1184. http://dx.doi.org/10.1111/jai.12919. 
DOURADO, E.C.S., NUNES, J.L.S. and PIORSKI, N.M., 2015. Ecomorphology and diet of two species of Acestrorhynchus from Brazilian Northeast. Cybium, vol. 39, no. 1, pp. 11-19.

FARIAS, E.U., LOEBENS, S.C., YAMAMOTO, K.C., SIQUEIRA-SOUZA, F.K., FREITAS, C.E.C., DOS ANJOS, H.D.B. and MAGALHÃES, E.R.S., 2017. Assembleia de peixes em lagos do rio Quiuini, um tributário do rio Negro, Amazonas, Brasil. Biota Amazônia, vol. 7, no. 1, pp. 74-81.

FRANZINELLI, E., 2011. Características morfológicas da confluência dos rios Negro e Solimões (Amazonas, Brasil). Brazilian Journal of Geology, vol. 41, pp. 587-596.

FREITAS, C.E.C., SIQUEIRA-SOUZA, F.K., FLORENTINO, A.C. and HURD, L.E., 2014. The importance of spatial scales to analysis of fish diversity in Amazonian floodplain lakes and implications for conservation. Ecology Freshwater Fish, vol. 23, no. 3, pp. 470477. http://dx.doi.org/10.1111/eff.12099.

FREITAS, C.E.C., SIQUEIRA-SOUZA, F.K., PRADO, K.L.L., YAMAMOTO, K.C. and HURD, L.E., 2010. Factors determining fish species diversity in Amazonian floodplain lakes. In N. RIJA and R. PRIETO, eds. Amazon basin: plant life, wildlife and environment. New York: Nova Science Publishers, pp. 41-76.

GERKING, S.D., 1994. Feeding ecology of fish. San Diego: Academic Press, $416 \mathrm{p}$.

GOMIERO, L.M., VILLARES JUNIOR, G.A. and NAOUS, F., 2010. Seasonal and ontogenetic variations in the diet of Cichla kelberi Kullander and Ferreira, 2006 introduced in an artificial lake in southeastern Brazil. Brazilian Journal of Biology $=$ Revista Brasileira de Biologia, vol. 70, no. 4, pp. 1033-1037. http://dx.doi. org/10.1590/S1519-69842010000500017. PMid:21180910.

GOULDING, M., 1980. The fishes and the forest: explorations in Amazonian natural history. Berkeley: University of California Press. http://dx.doi.org/10.1525/9780520316133.

GOULDING, M., 1990. Amazon: the flooded forest. Brasília: Sterling Publishing Company.

GROSSMAN, G.D., 1986. Food resources partitioning in a rocky intertidal fish assemblage. Journal of Zoology, vol. 1, no. 2, pp. 317-355. http://dx.doi.org/10.1111/j.1096-3642.1986.tb00642.x.

HAMADA, N. and FERREIRA-KEPPLER, R.L., 2012. Guia ilustrado de insetos aquáticos e semiaquáticos da Reserva Florestal Ducke. Manaus: Editora da Universidade Federal do Amazonas.

HAHN, N.S., DELARIVA, R.L. and LOUREIRO, V.E., 2000. Feeding of Acestrorhynchus lacustris (Characidae): a post impoundment studies on Itaipu reservoir, upper Paraná River, PR. Brazilian Archives of Biology and Technology, vol. 43, 207-213.

HAWLITSCHEK, O., YAMAMOTO, K. and CARVALHO NETO, F.G., 2013. Composición de la dieta de un ensamble de peces del lago tupe, Amazonas, Brasil. Revista Colombiana de Ciencia Animal, vol. 5 , no. 2, pp. 313. http://dx.doi.org/10.24188/recia.v5.n2.2013.296.

HOUDE, E.D. (1997). Patterns and consequences of selective processes in teleost early life histories. In: R.C. CHAMBERS and E.A. TRIPPEL, eds. Early life history and recruitment in fish populations. Dordrecht: Springer. Chapman \& Hall Fish and Fisheries Series, no. 21. http://dx.doi.org/10.1007/978-94009-1439-1_6.

HYNES, H.B.N., 1950. The food of fresh-water sticklebacks (Gasterosteus aculeatus and Pygosteus pungitius), with a review of methods used in studies of the food of fishes. Journal of Animal Ecology, vol. 19, no. 1, pp. 36. http://dx.doi.org/10.2307/1570.

HYSLOP, E.J., 1980. Stomach contents analysis-a review of methods and their application. Journal of Fish Biology, vol. 17, no. 4, pp. 411-429. http://dx.doi.org/10.1111/j.1095-8649.1980.tb02775.x.
JACOBI, C.M., VILLAMARÍN, F., CAMPOS-SILVA, J.V., JARDINE, T. and MAGNUSSON, W.E., 2020. Feeding of Arapaima sp.: integrating stomach contents and local ecological knowledge. Journal of Fish Biology, vol. 97, no. 1, pp. 265-272. http://dx.doi.org/10.1111/ jfb.14372. PMid:32383478.

JUNK, W.J., BAYLEY, P.B. and SPARKS, R.E., 1989. The flood pulse concept in river-floodplain systems. Canadian Special Publication of Fisheries and Aquatic Sciences, vol. 106, no. 1, pp. 101-127.

KAWAKAMI, E. and VAZZOLER, G., 1980. Método gráfico e estimativa de índice alimentar aplicado no estudo de alimentação de peixes. Brazilian Journal of Oceanography, vol. 29, no. 2, pp. 205-207. http://dx.doi.org/10.1590/S1679-87591980000200043.

KREBS, C.J., 1998. Ecological methodology. 2nd ed. Menlo Park: Benjamin Cummings.

KRINSKI, D., 2010. Dieta do peixe-cachorro Acestrorhynchus pantaneiro Menezes, 1992 (characidae: Acestrorhynchinae) do pantanal de Poconé, Mato Grosso, Brasil. Bioscience Journal, vol. 26, no. 2, pp. 287-295.

LATRUBESSE, E.M., 2012. Amazon lakes. In L. BENGTSSON, R.W. HERSCHY and R.W. FAIRBRIDGE, eds. Encyclopedia of lakes and reservoirs. Dordrecht: Springer Netherlands, pp. 13-26. https:// doi.org/10.1007/978-1-4020-4410-6.

LIPPARELLI, T., 1999. História natural do tucunaré Cichla cf. ocellaris. (Teleostei, Cichlidae) no rio Piquirí, pantanal de Paiaguás, Estado de Mato Grosso do Sul. São Paulo: Universidade Estadual Paulista, 296 p. Dissertação de Mestrado em Ciências Biológicas.

LOURENÇO, L.S., FERNANDES, I.M., PENHA, J. and MATEUS, L.A.F., 2012. Persistence and stability of cichlid assemblages in neotropical floodplain lagoons. Environmental Biology of Fishes, vol. 93, no. 3, pp. 427-437. http://dx.doi.org/10.1007/ s10641-011-9933-9.

MACEDO, M.G., SIQUEIRA-SOUZA, F.K. and FREITAS, C.E.C., 2015. Abundancia y diversidad de peces predadores en lagos de Várzea de la Amazonia Central. Revista Colombiana de Ciencia Animal Recia, vol. 7, no. 1, pp. 50. http://dx.doi.org/10.24188/ recia.v7.n1.2015.422.

MÉRONA, B. and RANKIN-DE-MÉRONA, J., 2004. Food resource partitioning in a fish community of the central Amazon floodplain. Neotropical Ichthyology, vol. 2, no. 2, pp. 75-84. http://dx.doi.org/10.1590/S1679-62252004000200004.

MERTES, L.A.K., DUNNE, T. and MARTINELLI, L.A., 1996. Channelfloodplain geomorphology along the Solimões-Amazon River, Brazil. Geological Society of America Bulletin, vol. 108, no. 9, pp. 1089-1107. http://dx.doi.org/10.1130/00167606(1996)108<1089:CFGATS>2.3.CO;2.

MEURER, S. and ZANIBONI-FILHO, E., 2012. Reproductive and feeding biology of Acestrorhynchus pantaneiro Menezes, 1992 (Osteichthyes: Acestrorhynchidae) in areas under the influence of dams in the upper Uruguay River, Brazil. Neotropical Ichthyology, vol. 10, no. 1, pp. 159-166. http://dx.doi.org/10.1590/ S1679-62252012000100015.

MOREIRA, A.A.N., 1977. Geography of Brazil. Rio de Janeiro: Fundação Instituto Brasileiro de Geografia e Estatística.

NEVE DOS SANTOS, R., AMADIO, S. and FERREIRA, E.J.G., 2010. Patterns of energy allocation to reproduction in three Amazonian fish species. Neotropical Ichthyology, vol. 8, no. 1, pp. 155-162. http://dx.doi.org/10.1590/S1679-62252010005000001.

NEVES DOS SANTOS, R., FERREIRA, E.J.G. and AMADIO, S., 2008. Effect of seasonality and trophic group on energy acquisition in Amazonian fish. Ecology Freshwater Fish, vol. 17, no. 2, pp. 340-348. http://dx.doi.org/10.1111/j.1600-0633.2007.00275.x.

NOVAKOWSKI, G.C., HAHN, N.S. and FUGI, R., 2008. Diet seasonality and food overlap of the fish assemblage in a pantanal pond. 
Neotropical Ichthyology, vol. 6, no. 4, pp. 567-576. http://dx.doi. org/10.1590/S1679-62252008000400004.

PAULY, D., FROESE, R., SA-A, P.S., PALOMARES, M.L., CHRISTENSEN, V. and RIUS, J., 2000. TrophLab manual. Manila: ICLARM.

PAULY, D. and PALOMARES, M.L., 2000. Approaches for dealing with three sources of bias when studying the fishing down marine food web phenomenon. Fishing Down the Mediterranean Food Webs, vol. 12, pp. 61-66.

PIANKA, E.R., 1973. The structure of lizard communities. Annual Review of Ecology and Systematics, vol. 4, no. 1, pp. 53-74. http:// dx.doi.org/10.1146/annurev.es.04.110173.000413.

PONTE, S.C.S., FERREIRA, L.C.F., BITTENCOURT, S., QUEIROZ, H. and ZACARDI, D., 2016. Variação espacial e temporal das larvas de Triportheus (Characiformes, Triportheidae), no médio Rio Solimões, Amazônia Central, Brasil. Acta of Fisheries and Aquatic Resources, vol. 4, no. 2, pp. 71-81. http://dx.doi.org/10.2312/ Actafish.2016.4.2.71-81.

PORTO DE MANAUS, 2021 [viewed 2 July 2021]. Porto de Manaus: o coração da Amazônia [online]. Available from: https://www. portodemanaus.com.br/

QUEIROZ, M.M.A., HORBE, A.M.C., SEYLER, P. and MOURA, C.A.V., 2009. Hidroquímica do rio Solimões na região entre Manacapuru e Alvarães - Amazonas - Brasil. Acta Amazonica, vol. 39, no. 4, pp. 943-952. http://dx.doi.org/10.1590/S004459672009000400022

RAMÍREZ, F., DAVENPORT, T.L. and MOJICA, J.I., 2015. Dietarymorphological relationships of nineteen fish species from an Amazonian terra firme blackwater stream in Colombia. Limnologica, vol. 52, pp. 89-102. http://dx.doi.org/10.1016/j. limno.2015.04.002.

ROCHA, A.A.F., SANTOS, N.C.L., PINTO, G.A., MEDEIROS, T.N. and SEVERI, W., 2011. Diet composition and food overlap of Acestrorhynchus britskii and A. lacustris (Characiformes: Acestrorhynchidae) from Sobradinho reservoir, São Francisco river, Bahia State. Acta Scientiarum. Biological Sciences, vol. 33 , no. 4, pp. 407-415. http://dx.doi.org/10.4025/actascibiolsci. v33i4.7240.

RÖPKE, C.P., PIRES, T.H.S., WINEMILLER, K.O., DE FEX WOLF, D., DEUS, C.P. and AMADIO, S., 2019. Reproductive allocation by Amazon fishes in relation to feeding strategy and hydrology. Hydrobiologia, vol. 826, no. 1, pp. 291-305. http://dx.doi. org/10.1007/s10750-018-3740-7.

ROTTA, M.A., 2003 [viewed 2 July 2021]. Aspectos gerais da fisiologia e estrutura do sistema digestivo dos peixes relacionados à piscicultura [online]. Corumbá: Embrapa Pantanal. Documentos. Available from: https://www.infoteca.cnptia.embrapa.br/bitstream/ doc/811108/1/DOC53.pdf

SANTOS, G.M., FERREIRA, E.G. and ZUANON, J.A.S., 2009. Peixes comerciais de Manaus. $2^{2}$ ed. Manaus: Editora INPA.

SILVA, A. and GOITEIN, R., 2009. Diet and feeding activity of Acestrorhynchus lacustris in the water reservoir at Ribeirão Claro, SP. Brazilian Journal of Biology = Revista Brasileira de Biologia, vol. 69, no. 3, pp. 757-762. http://dx.doi.org/10.1590/ S1519-69842009000400002. PMid:19802434.

SIOLI, H. 1984. The Amazon and its main affluents: hydrography, morphology of the river courses, and river types. In: H. SIOLI, ed. The Amazon. Dordrecht: Springer, pp. 127-165. http://dx.doi. org/10.1007/978-94-009-6542-3_5.

SIOLI, H., 1951. Some results and problems of the Amazon limnology. Belém: Ipe.

SOARES, M.G.M., COSTA, E.L., SIQUEIRA-SOUZA, F.K., ANJOS, H.D.B., YAMAMOTO, K.C. and FREITAS, C.E.C., 2007. Peixes de lagos do médio rio Solimões. $1^{\underline{a}}$ ed. Manaus: EDUA.

SVANBÄCK, R. and BOLNICK, D.I., 2008. Food specialization. Behavioral Ecology, vol. 5, pp. 839-844.

SVANBÄCK, R., RYDBERG, C., LEONARDSSON, K. and ENGLUND, G., 2011. Diet specialization in a fluctuating population of Saduria entomon: a consequence of resource or forager densities? Oikos, vol. 120, no. 6, pp. 848-854. http://dx.doi.org/10.1111/j.16000706.2010.18945.x.

VILLAMIZAR, E.A.R., ADENEY, J.M., PIEDADE, M.T.F. and JUNK, W.J., 2020. Hydrochemical classification of Amazonian rivers: a systematic review and meta-analysis. Caminhos de Geografia, vol. 21, no. 78, pp. 211-226. http://dx.doi.org/10.14393/ RCG217853272.

VILLARES JUNIOR, G.A. and GOITEIN, R., 2016. Morphological aspects in the ontogeny of Salminus hilarii Valenciennes, 1850 (Ostaryophysi: characidae). Brazilian Journal of Biology = Revista Brasileira de Biologia, vol. 76, no. 4, pp. 905-911. http://dx.doi. org/10.1590/1519-6984.04315. PMid:27143050.

WARD, A.J., WEBSTER, M.M. and HART, P.J., 2006. Intraspecific food competition in fishes. Fish and Fisheries, vol. 7, no. 4, pp. 231-261. http://dx.doi.org/10.1111/j.1467-2979.2006.00224.x.

WOOTTON, R.J., 1990. Ecology of teleost fishes. $1^{\text {st }}$ ed. Dordrecht: Springer Netherlands. https://doi.org/10.1007/978-94-0090829-1.

ZUANON, J. and FERREIRA, E., 2008. Feeding ecology of fishes in the Brazilian Amazon: a naturalistic approach. In: J.E.P. CYRINO, ed. Feeding and digestive functions in fishes. USA: Science Publishers, pp. 1-34. http://dx.doi.org/10.1201/b10749-2. 